\title{
Salmonella in free-living exotic and native turtles and in pet exotic turtles from SW Spain
}

\author{
J. Hidalgo-Vila ${ }^{a, *}$, C. Díaz-Paniagua ${ }^{a}$, N. Pérez-Santigosa ${ }^{a}$, C. de Frutos-Escobar ${ }^{b}$, \\ A. Herrero-Herrero ${ }^{b}$ \\ a Estación Biológica de Doñana, CSIC, Avda. María Luisa s/n, 41013 Sevilla, Spain \\ ${ }^{\mathrm{b}}$ Laboratorio Central de Veterinaria, Ministerio de Agricultura, Pesca y Alimentación. Ctra. de Algete, Km 8, 28110 Algete, Madrid, Spain
}

\begin{abstract}
We screened 78 native and 94 exotic turtles from natural ponds and 39 exotic pet turtles for presence of Salmonella, resulting with infection rates of $6.61 \%, 6.4 \%$, and $5.1 \%$, respectively. Concurrent shedding of multiple serotypes of the bacteria was only detected in one pet turtle. Eleven isolates were obtained in free-living turtles, including serotypes commonly found in reptiles and also the serotype Typhimurium, which is commonly related to human infections. In pet turtles, the five serotypes isolated were different to those isolated in free-living turtles and had been reported to cause reptile-associated salmonellosis in humans. These results confirm the risk of transmission of Salmonella from free-living and pet turtles to humans, demanding the necessity of regulation of pet turtle trade in Europe.
\end{abstract}

Keywords: Pet turtles; Free-living turtles; Health risk; Salmonella; Reptile-associated salmonellosis

In 1975, an important increase of salmonellosis in humans related to turtles was the cause for banning the sale of turtles with carapace length of $4 \mathrm{in}$. or less in USA. However, the ban did not apply to exports, which has increased greatly in the last decades (Warwick et al., 2001). At present, millions of turtles have been exported from USA farms into other countries of America, Asia, Africa and Europe (Salzberg, 1995; Telecky, 2001; Reed and Gibbons, 2003). In Europe, the import of Trachemys scripta elegans is forbidden since 1997 (Comision Regulation (EC) No. 2551/97 of 15 December 1997). However, similar high numbers of pet turtles of other species or subspecies are presently imported, and are commonly sold as popular pets.

Chelonians are important carriers of Salmonella (Vincent et al., 1960; Chiodini and Sundberg, 1981; Pasmans et al., 2000; Briones et al., 2004; Hidalgo-Vila et al., \footnotetext{
1457.

* Corresponding author. Tel.: +44 (0) 207449 6489; fax: +44 (0) 207586

E-mail address: judit@ebd.csic.es (J. Hidalgo-Vila).
}

2007, 2008) and reptiles have been frequently reported as responsible for salmonellosis in humans, especially in children (Mermin et al., 1997; Woodward et al., 1997; Warwick et al., 2001; Mermin et al., 2004; Corrente et al., 2006). However, at present, there are no laws in Europe regulating the trade and safe keeping of turtles in captivity.

The aim of this study was to analyse the prevalence of Salmonella in pet turtles, as well as in wild populations of exotic and native turtles, and to evaluate the potential health risks of transmission for humans and native fauna.

Established populations of Trachemys scripta elegans cohabiting with native turtles populations have been described in two localities in SW Spain (Pérez-Santigosa et al., 2006). During 2003-2004, we examined the presence of Salmonella in 172 adult turtles (78 native turtles and 94 exotic turtles) from these two localities (Acebuche Lagoon and Portil Lagoon, Huelva, Spain), and 39 exotic pet turtles provided by their owners (from Seville, Spain) (Table 1). Among free-living exotic turtles, individuals of Trachemys scripta elegans may be assumed to come from successful reproduction of this species in the area, while 
Table 1

Infection rates of Salmonella in free-living native and exotic turtles and in pet exotic turtles and number of positive individuals registered of each species and locality

\begin{tabular}{|c|c|c|c|c|}
\hline & \multirow{2}{*}{$\begin{array}{l}\text { No. } \\
\text { animals }\end{array}$} & \multirow[t]{2}{*}{ positives } & \multicolumn{2}{|c|}{ Total } \\
\hline & & & $\mathrm{N}$ & $\begin{array}{l}\text { Positive } \\
(\%)\end{array}$ \\
\hline Native free-living turtles & & & 78 & $5(6.61 \%)$ \\
\hline \multicolumn{5}{|l|}{ Acebuche Lagoon } \\
\hline Mauremys leprosa & 8 & 0 & & \\
\hline Emys orbicularis & 14 & 0 & & \\
\hline \multicolumn{5}{|l|}{ Portil Lagoon } \\
\hline Mauremys leprosa & 55 & 5 & & \\
\hline Emys orbicularis & 1 & 0 & & \\
\hline $\begin{array}{l}\text { Free-living exotic turtles } \\
\text { Acebuche Lagoon }\end{array}$ & & & 94 & $6(6.38 \%)$ \\
\hline Trachemys scripta elegans & 52 & 4 & & \\
\hline \multicolumn{5}{|l|}{ Portil Lagoon } \\
\hline Trachemys scripta elegans & 36 & 1 & & \\
\hline Trachemys scripta scripta & 3 & 0 & & \\
\hline Graptemys kohni & 1 & 1 & & \\
\hline $\begin{array}{l}\text { Graptemys } \\
\text { pseudogeographica }\end{array}$ & 2 & 0 & & \\
\hline Exotic pet turtles & & & 39 & $2(5.1 \%)$ \\
\hline Trachemys scripta elegans & 23 & 0 & & \\
\hline Trachemys scripta scripta & 6 & 0 & & \\
\hline Trachemys ornata & 2 & 0 & & \\
\hline Trachemys emolli & 1 & 1 & & \\
\hline Graptemys kohni & 3 & 0 & & \\
\hline $\begin{array}{l}\text { Graptemys } \\
\text { pseudogeographica }\end{array}$ & 2 & 0 & & \\
\hline Pseudemys nelsoni & 2 & 1 & & \\
\hline
\end{tabular}

individuals of other species of exotic turtles have been recently released by their owners (Pérez-Santigosa et al., 2006).

Because this study was made within the framework of a program for eradication of exotic turtles, all the exotic individuals captured in the wild were euthanized with Thiopental sodium injection (Tiobarbital, Braun Medical). Samples of liver, lungs, kidneys, digestive tract and pancreas of these animals were analysed to evaluate the prevalence of Salmonella.

For native and pet turtles only cloacal samples were analysed. Because bacteria excretion is not continuous, three samples (one on the day of capture, and the other two samples on subsequent days) were taken from the cloacae to each individual using cotton sterile swabs. In order to prevent Salmonella transmission among individuals, turtles were kept singly and gloves were changed each time an animal was handled.

All samples were stored at $4{ }^{\circ} \mathrm{C}$ in Stuart transport medium (Invasive Sterile EUROTUBO ${ }^{\circledR}$ ) for 1-4 days before cultivation and identification of Salmonella isolates in the National Reference Laboratory for Animal Salmonellosis in Spain (Laboratorio Central de Veterinaria, Algete, MAPA).

Cultivation of bacteria was made according to ISO 6579: 2002, and Amended ISO 6579:2002/DAM. Suspect salmonellae colonies were removed for identification by biochemical and serological tests. Serotyping was performed according to Kauffmann-White scheme (Popoff, 2001).

In general, the infection rates of Salmonella detected in free-living turtles were moderate (Table 1). Salmonella was isolated in similar proportions in exotic and native wild turtles $\left(v^{2}=0.001, p=0.994\right)$. Infections were detected in exotic turtles of the two localities investigated, while infections in native turtles were detected only in Portil Lagoon (Table 1). In this locality, native freshwater turtles (Mauremys leprosa), showed a prevalence of infection of $9.0 \%$, while only $2.7 \%$ exotic red eared sliders (T. s. elegans) were infected. The only map turtle (Graptemys kohni) captured in this lagoon was also infected by the bacteria (Table 1). As in free-living turtles, total infection rate of Salmonella in pet turtles was $5.1 \%$, with only two individuals infected (Table 1). These results are similar to the prevalence registered in previous studies in aquatic turtles (Abalem de Sá and Solari, 2001; Hidalgo-Vila et al., 2007). However, high prevalence of the bacteria $(>70 \%)$ have been reported in terrestrial tortoises (Vincent et al., 1960; Pasmans et al., 2000; Hidalgo-Vila et al., 2007, 2008).

The serotypes isolated in free-living turtles did not coincide with those isolated in pet turtles. Eleven isolates belonging to the species Salmonella enterica were obtained in free-living turtles. Eight were included in the subspecies enterica (I), and the remaining belonged to the subspecies salamae (II), although some of them could not be totally identified (Table 2). No more than one serotype was iso-

Table 2

Isolated serotypes of Salmonella in native and exotic free-living turtles and in exotic pet turtles

\begin{tabular}{|c|c|c|c|}
\hline & $\begin{array}{l}\text { Number of } \\
\text { infected turtles }\end{array}$ & Subspecies & $\begin{array}{l}\text { Serotype (number } \\
\text { of isolates) }\end{array}$ \\
\hline \multicolumn{4}{|l|}{ Free-living turtles } \\
\hline \multicolumn{4}{|l|}{ Acebuche Lagoon } \\
\hline Trachemys & 4 & I & Potsdam (1) \\
\hline \multirow{3}{*}{ scripta elegans } & & I & Bredeney (1) \\
\hline & & I & Typhimurium (1) \\
\hline & & II & $4,12,27: b:[e, n, x](1)$ \\
\hline \multicolumn{4}{|l|}{ Portil Lagoon } \\
\hline Mauremys & 5 & I & Potsdam (2) \\
\hline \multirow[t]{3}{*}{ leprosa } & & I & Bredeney (1) \\
\hline & & I & Kottbus (1) \\
\hline & & II & 9,12: $\mathrm{Z}_{29}:(\mathrm{NI})(1)$ \\
\hline $\begin{array}{l}\text { Trachemys } \\
\text { scripta elegans }\end{array}$ & 1 & $\mathrm{I}$ & Anatum (1) \\
\hline $\begin{array}{l}\text { Graptemys } \\
\text { kohni }\end{array}$ & 1 & II & 9,12: $\mathrm{Z}_{29}:(\mathrm{NI})(1)$ \\
\hline \multicolumn{4}{|l|}{ Pet turtles } \\
\hline $\begin{array}{l}\text { Pseudemys } \\
\text { nelsoni }\end{array}$ & 1 & I & Altona (1) \\
\hline Trachemys & 1 & I & Altona (1) \\
\hline \multirow{3}{*}{$\begin{array}{l}\text { Trachemys } \\
\text { emolli }\end{array}$} & & I & Panama (1) \\
\hline & & I & Sandiego (1) \\
\hline & & I & Saintpaul(1) \\
\hline
\end{tabular}

(NI): second phase flagellar antigen not identified. 
lated per individual. The serotypes most frequently identified were Potsdam and Bredeney, both isolated in exotic and native turtles from both localities (Table 2). Kottbus and 9,12:z29: (II) were also isolated in native turtles whereas Typhimurium, Anatum, 9,12:z29: (II) and 4,12,27:b: [e,n, $\mathrm{x}$ ] (II) were identified in the exotic ones (Table 2). All serotypes identified have been also isolated in humans during the last years (Olsen et al., 2001; CDC, 2003; Enter-net 2006). The most prevalent, Potsdam, has been previously reported in reptiles (Vincent et al., 1960; Briones et al., 2004; Hidalgo-Vila et al., 2008), although it is not one of the most common serotypes affecting humans. Indeed, it has been identified as the most abundant serotype of aquatic and terrestrial turtles of another locality in southwestern Spain (HidalgoVila et al., 2007). Bredeney is usually included between the main serotypes identified in Europe (Enter-net 2006) and is a common serotype in aquatic environments (Polo et al., 1999; Baudart et al., 2000). The detection of Typhimurium in free-living turtles is relevant, because it is a highly pathogenic serotype and is commonly associated to severe infections in humans. This is, together with Enteriditis, one of the most abundant serotypes of Salmonella isolated from humans (Chiodini and Sundberg, 1981; Baird-Parker, 1990; IFST, 1997; Olsen et al., 2001; Enternet 2006). The other serotypes identified Kottbus and Anatum, are commonly isolated in natural environments (Polo et al., 1999; Baudart et al., 2000), and are frequently isolated in reptiles (Abalem de Sá and Solari, 2001; Briones et al., 2004).

In pet turtles, five isolates included in subspecies enterica (I) were obtained (Table 2). Four serotypes were identified being Altona the most frequent (Table 2). This serotype has been reported from food pellets and cattle (de Frutos et al., 2005), while Saintpaul, Sandiego and Panama are commonly identified in the environment (Polo et al., 1999; Baudart et al., 2000) and in reptiles (Woodward et al., 1997; Pasmans et al., 2000; Pasmans et al., 2005).

All serotypes isolated in our pet turtles had been previously reported as cause of turtle-associated salmonellosis in humans (Chiodini and Sundberg, 1981; Woodward et al., 1997; CDC, 2003). However, the serotypes identified in free-living turtles had been commonly related to other sources of infections in humans (Baird-Parker, 1990; Olsen et al., 2001; Unicomb et al., 2003).

Among pet turtles, we detected one individual of Trachemys emolli with concurrent shedding of four serotypes. This could be caused by the poor hygienic conditions of turtle rearing; a fact that could depress the immune system and increases the risk of transmission of the bacteria among individuals and the risk of salmonellosis in humans (Kaplan, 1998).

Considered one of the most important public health disease problems, salmonellosis is the most widespread disease affecting animals and humans (Woodward et al., 1997). In Europe, health risks associated to reptiles have not been considered, and small turtles are common pets frequently traded for children owners, who usually do not preserve hygienic requirements to avoid infections.

The detection of Salmonella in pet and free-living turtles confirms that these species are potential carriers of the bacteria. Although the prevalence of Salmonella detected in turtles of this study was moderate, highly pathogen serotypes were found in pet turtles indicating their potential risk of transmissions to humans. Therefore, pet turtle trade should be accompanied with sound advertisements for purchasers about their health risks. Their handling should be recommended with appropriate hygienic conditions and avoided or even forbidden for children. As in USA, the regulation of pet turtle's trade is also necessary in all other countries in which they are imported.

\section{Acknowledgements}

We thank X. Ruiz, A. Portheault, M. Florencio, A. Conejo, E. Ortiz and J.L. Ayala for their field and laboratory assistance and to I. Gómez-Mestre for his comments to the manuscript. J. Hidalgo-Vila was financed by I3PCSIC research grant. This study was supported by Consejería de Medio Ambiente-Junta de Andalucía (UE cofinanciated project).

\section{References}

Abalem de Sá, I.V., Solari, C.A., 2001. Salmonella in brazilian and imported pet reptiles. Brazilian Journal of Microbiology 32, 293-297.

Baird-Parker, A.C., 1990. Foodborne salmonellosis. Lancet 17, 12311235.

Baudart, J., Lemarchand, K., Brisabois, Lebaron, P., 2000. Diversity of Salmonella strains isolated from the aquatic environment as determined by serotyping and amplification of the ribosomal DNA spacer regions. Applied and Environmental Microbiology 66, 1544-1552.

Briones, V., Téllez, S., Goyache, J., Ballesteros, C., Lanzarot, M.P., Domínguez, L., Fernández-Garayzábal, J., 2004. Salmonella diversity associated with wild reptiles and amphibians in Spain. Environmental Microbiology 6, 868-871.

CDC, 2003. Salmonella Surveillance Summary, 2002. US Department of Health and Human Services, CDC, Atlanta, Georgia.

Chiodini, R.J., Sundberg, J.P., 1981. Salmonellosis in reptiles: a review. American Journal of Epidemiology 113, 494-499.

Corrente, M., Totaro, M., Martella, V., Campolo, M., Lorusso, A., Ricci, M., Buonavoglia, C., 2006. Reptile-associated salmonellosis in man, Italy. Emerging Infectious Diseases 12 (2), 358-359.

de Frutos, C., Ortiz, E., Herrero, A., Ayala, J.L., Fernández, B., 2005. Análisis de los serotipos de Salmonella spp. aislados durante los años 2002, 2003 y 2004 por los Laboratorios de Sanidad Animal en España. Boletín Epidemiológico Semanal 13, 133-144.

Enter-net, 2006. Enter-net Quarterly Salmonella Report Oct-Dec 2006/4. $<$ www.hpa.org.uk> (accessed February 2007).

Hidalgo-Vila, J., Díaz-Paniagua, C., de Frutos-Escobar, C., JiménezMartínez, C., Pérez-Santigosa, N., 2007. Salmonella in free-living terrestrial and aquatic turtles. Veterinary Microbiology 119, 311-315.

Hidalgo-Vila, J., Díaz-Paniagua, Ruiz, X., Portheault, A., El Mouden, H., Slimani, T.C., de Frutos-Escobar, C., De Caso, M.S., 2008. Salmonella in free-living spur-thighed (Testudo graeca) from Central Western Morocco. Veterinary Record 162 (7), 218-219.

IFST, 1997. Institute of Food Science and Technology (UK). Current Hot Topics. Salmonella typhimurium DT 104 (1997) (<http:// www.ifst.org>). 
Kaplan, M., 1998. Reptile rehabilitation. In: Ackerman, L. (Ed.), The Biology Husbandry and Health Care of Reptiles. T.F.H. Publishing, New Jersey, pp. 898-941.

Mermin, J., Hoar, B., Angulo, F.J., 1997. Iguanas and Salmonella marina infection in children: a reflection of the increasing incidence of reptileassociated salmonellosis in the United States. Pediatrics 99, 399-402.

Mermin, J., Hutwagner, L., Vugia, D., Shallow, S., Daily, P., Bender, J., Koehler, J., Marcus, R., Angulo, F.J., 2004. Reptiles, amphibians, and human Salmonella infection: a population-based, case-control study. Clinical Infectious Diseases 38, S253-S261.

Olsen, S.J., Bishop, R., Brenner, F.W., Roels, T.H., Bean, N., Tauxe, R.V., Slutsker, L., 2001. The changing epidemiology of Salmonella: trends in serotypes isolated from humans in the United States, 19871997. Journal of Infectious Disease 183, 753-761.

Pasmans, F., De Herdt, P., Chasseur-Libotte, M.L., Ballasina, D.L., Haesebrouck, F., 2000. Occurrence of Salmonella in tortoises in a rescue centre in Italy. Veterinary Record 146, 256-258.

Pasmans, F., Martel, A., Boyen, F., Vandekerchove, D., Wybo, I., Van Immerseel, F., Heyndrickx, M., Collard, J.M., Ducatelle, R., Haesebrouck, F., 2005. Characterization of Salmonella isolates from captive lizards. Veterinary Microbiology 110, 285-291.

Pérez-Santigosa, N., Díaz-Paniagua, C., Hidalgo-Vila, J., Marco, A., Andreu, A.C., Portheault, A., 2006. Características de dos poblaciones reproductoras del galápago de Florida, Trachemys scripta elegans, en el suroeste de España. Revista Española de Herpetología 20, 5-16.

Polo, F., Figueras, M.J., Inza, I., Sala, J., Fleisher, J.M., Guarro, J., 1999. Prevalence of Salmonella serotypes in environmental waters and their relationships with indicator organisms. Antonie van Leeuwenhoek 75, 285-292.

Popoff, M.Y., 2001. Antigenic Formulas of the Salmonella Serovars, eighth ed. WHO Collaborating Centre for Reference and Research on Salmonella, Institut Pasteur, Paris.

Reed, R.N., Gibbons, J.W. 2003. Conservation status of live US nonmarine turtles in domestic and international trade. A Report to: US Department of the Interior and US Fish and Wildlife Service. 18 January $2005<$ www.tiherp.org/docs/Library/Turtle_trade_report. $\mathrm{pdf}>$.

Salzberg, A. 1995. Report on import/export turtle trade in the United States. In: Proceedings of the International Congress of Chelonian Conservation, pp. 314-322.

Telecky, T.M., 2001. United States import and export of live turtles and tortoises. Turtle and Tortoise News 4, 8-13.

Unicomb, L., Bird, P., Dalton, C., 2003. Outbreak of Salmonella potsdam associated with salad dressing at a restaurant. Communicable Diseases Intelligence 27, 508-512.

Vincent, J., Neel, R., Le Minor, L., 1960. Les Salmonella des tortues. Contribution à l'étude des Salmonella du Maroc. Archives de L'Institut Pasteur de Tunis 37, 187-194.

Warwick, C., Lambiris, A.J.L., Westwood, D., Steedman, C., 2001. Reptile-related salmonellosis. Journal of the Royal Society of Medicine 94, 124-126.

Woodward, D.L., Khakhria, R., Johnson, W.M., 1997. Human salmonellosis associated with exotic pets. Journal of Clinical Microbiology $35,2786-2790$. 